Please do not remove this page

RMIT

UNIVERSITY

\title{
The frequency and severity of operational losses: a cross-country comparison
}

Moosa, Imad; Li, Qiang

https://researchrepository.rmit.edu.au/esploro/outputs/9921861928801341/filesAndLinks?institution=61RMIT_INST\&index=null

Moosa, I., \& Li, Q. (2013). The frequency and severity of operational losses: a cross-country comparison. Applied Economics Letters, 20(2), 167-172. https://doi.org/10.1080/13504851.2012.684777

Document Version: Accepted Manuscript

Published Version: https://doi.org/10.1080/13504851.2012.684777

Repository homepage: https://researchrepository.rmit.edu.au

(C) 2013 Copyright Taylor and Francis Group, LLC.

Downloaded On 2023/04/26 14:07:59 +1000

Please do not remove this page 
Thank you for downloading this document from the RMIT Research Repository.

The RMIT Research Repository is an open access database showcasing the research outputs of RMIT University researchers.

RMIT Research Repository: http://researchbank.rmit.edu.au/

\section{Citation:}

Moosa, I and Li, L 2013, 'The frequency and severity of operational losses: a cross-country comparison ', Applied Economics Letters , vol. 20, no. 2, pp. 167-172.

See this record in the RMIT Research Repository at:

http://researchbank.rmit.edu.au/view/rmit:18124

Version: Accepted Manuscript

Copyright Statement: (c) 2013 Copyright Taylor and Francis Group, LLC.

Link to Published Version:

http://dx.doi.org/10.1080/13504851.2012.684777 


\title{
The Frequency and Severity of Operational Losses: A Cross-Country
}

\section{Comparison $^{\#}$}

\author{
IMAD MOOSA AND LARRY LI ${ }^{*}$ \\ SCHOOL OF ECONOMics, FinANCE AND MARKETING
}

RMIT

\begin{abstract}
We examine the proposition that cross-country differences in the factors determining the frequency and severity of operational losses lead to cross-country differences in the distribution and incidence of operational loss events in terms of frequency and severity. For this purpose we consider 4388 operational loss events covering eleven countries or country groups. The results reveal differences with respect to the type of loss events prevailing in each country or country group as well as differences with respect to the dominance of events of certain type in a particular business line and corporate entity type.
\end{abstract}

\section{JEL Classification: G21}

Keywords: Operational Risk, Basel II, Operational Loss Events, Business Lines

\footnotetext{
\# The first author is grateful to the Australian Research Council for the Discovery Grant used to finance work on this project. We are also grateful to the Australian Centre for Financial Studies for a research grant.

* The corresponding author. Address: School of Economics, Finance and Marketing, RMIT, 239 Bourke Street, Melbourne, Victoria 3000, Australia. E-mail:larry.li@rmit.edu.au.
} 


\section{Introduction}

Operational risk is the risk of (operational) losses resulting from the failure of people, processes, systems, and from external factors. Thus, operational risk is classified (by source or cause) under four headings: people risk, process risk, technology risk, and external risk. People risk arises from employee error, employee misdeeds, employee unavailability, and inadequate employee development and recruitment. Process risk arises from the inefficiency or ineffectiveness of various business processes within the firm. These include value-driving processes—such as sales and marketing, product development and customer support-and value-supporting processes such as human resources and legal matters. Technology (or system) risk arises from the system failures caused by breakdown, data quality and integrity issues, inadequate capacity, and poor project management. Finally, external risk is the risk of loss caused by the actions of external parties (for example, competitor behaviour, external fraud and regulatory changes) as well as macroeconomic and socioeconomic events.

Although the definition and sources of operational risk as described above sound straightforward, it is not easy to pinpoint the causes of operational losses empirically—indeed very few studies have attempted that. Some attempts have been made to model operational risk in terms of macroeconomic variables. Chernobai et al. (2007) analyse 1159 loss events endured by 160 U.S. banks over the period 1980-2003 in terms of both firm-specific features and macroeconomic variables. They conclude that "while there is some evidence that operational losses are more frequent and more severe during economic downturns, overall the macroeconomic environment tends to be less important than firm-specific characteristics such as size, leverage, volatility, profitability and the number of employees”. In particular they identified the 
importance of size, leverage, volatility, book-to-market, profitability, and the number of employees to be important determinants of operational losses. Another finding is that operational losses are more frequent and more severe during economic downturns. Moosa (2011) also found some evidence for the cyclical behaviour of operational risk, using the unemployment rate as the cyclical macroeconomic variable.

Size has been the most widely used firm-specific explanatory variable, perhaps because Basel II suggests that size is important. Under the basic indicators approach of Pillar 1 of Basel II, banks are required to calculate regulatory capital against operational risk as 15 per cent of gross income, which is a measure of size. However, it is often suggested that neither the empirical evidence, nor theory and not even intuition supports the importance of size as a determinant of operational losses (see, for example, Herring 2002; Peizer, 2003; de Fontnouvelle et al., 2005; Jobst, 2007).

Very few studies deal with firm-specific factors formally, perhaps because of the data problems typically encountered in studies of operational risk. For example, Bar et al. (2008) consider the effect of management style in hedge funds. Specifically, they focus on the decision to employ a team instead of a solo manager to manage a specific fund, providing evidence that this might help to reduce the probability of misconduct of fund managers and, consequently, to reduce operational risk. They conclude that teams behave more in line with investors' interests than solo managers along several dimensions: their investment styles are more reliable, they engage less in tournament behaviour, and their performance is more stable over time. The costs of this form of operational risk management seem small. Brown et al. (2007) argued that mandatory disclosure is a regulatory tool intended to allow market participants to assess 
operational risk. They examine the value of disclosure through the controversial SEC requirement that major hedge funds register as investment advisors and file disclosures. Their findings suggest that regulators should account for the endogenous production of information and the marginal benefit of disclosure to different investment clienteles.

The objective of this paper is not to consider the sources or causes of operational losses but rather to examine the following proposition. Since the firm-specific determinants of operational losses are likely to vary across countries, the profile of operational losses must exhibit cross-country differences. More specifically we make an attempt to find out if the association between event type and business lines and corporate entity type differs across countries or country groups.

\section{Hypotheses and Methodology}

Four hypotheses are tested using data covering 11 countries and country groups. The hypotheses can be stated as follows:

Hypothesis 1: The frequency of a loss event of a certain type is independent of the business line.

Hypothesis 2: The severity of a loss event of a certain type is independent of the business line.

Hypothesis 3: The frequency of a loss event of a certain type is independent of the corporate entity type.

Hypothesis 4: The severity of a loss event of a certain type is independent of the corporate entity type. 
The hypotheses are tested by constructing $n \times m$ contingency tables (containing $n$ rows and $m$ columns). For hypotheses 1 and 2, the rows and columns represent event types and business lines, respectively. For hypotheses 3 and 4, the rows represent event types whereas the columns represent corporate entity types. If $O_{i j}$ is the cell falling in row $i$ and column $j$, then

$$
\left.\begin{array}{l}
R_{i}=\sum_{j=1}^{m} O_{i j} \\
C_{j}=\sum_{i=1}^{n} O_{i j}
\end{array}\right\}
$$

Hence the total number of observations, $N$, is given by

$$
N=\sum_{i=1}^{n} R_{i}=\sum_{j=1}^{m} C_{j}
$$

Under the null that there is no association between rows and columns, the estimated value of the observation in each cell is given by

$$
E_{i j}=\frac{R_{i} C_{j}}{N}
$$

for $i=1, \ldots . . n$ and $j=1, \ldots . . m$. The test is based on the magnitudes of the actual observations, $O_{i j}$, and the expected values of these observations, $E_{i j}$. The null of no association is rejected if

$$
\sum_{i=1}^{n} \sum_{j=1}^{m} \frac{\left(O_{i j}-E_{i j}\right)^{2}}{E_{i j}}>\chi^{2}((n-1)(m-1))
$$

Rejection of the null hypothesis implies that the frequency or severity of events of a certain type tend to be greater in certain business lines or corporate entity type than in others. 


\section{A Description of the Data Set}

Data on the operational losses endured by firms across all sectors worldwide were obtained from the Fitch (First) qualitative database, which contains long write-ups and useful information about loss events obtained from multiple sources. This database provides a comprehensive analysis of the circumstances under which loss events occur, but no supplementary data on the underlying firms are provided. The focus of the qualitative databases of operational losses is not on capturing every event that takes place but rather to examine events that are of greater relevance and interest to subscribers.

The data sample comprises 4388 loss events going back to 1975. Eleven countries and country groups are considered: Africa, Canada, China, East Asia, Europe, Middle East, Oceania, Latin America, U.K. and U.S. The decision to consider a country on its own or as part of a country group depends on the number of operational loss events reported for each country. As a rule of thumb, a country was considered on its own if it had a record of at least 75 events.

Operational losses are examined by classifying them under event types, business lines and corporate entity types - the categories are displayed in Table 1. Event types and business lines are those used by the Basel Committee on Banking Supervision (see, for example, BCBS, 2004). Therefore "other” means event types and business lines that do not belong to any one of the categories used by the BCBS. The reason for the emergence of "other" kinds of event type and business line is that the BCBS categories are designed for banks only, since the Basel II and Basel III accords cover 
banks only. The loss events examined in this study cover ten corporate entity types as classified by the Fitch Risk database.

Figure 1 shows the distribution of the frequency and severity of operational losses by event type, business line and corporate entity type of the total loss losses, irrespective of the geographical location. We can see that the most dominant loss event in terms of both frequency and severity is CPBP, which represents the losses arising from failure to meet obligations to clients or from the design of a product. ${ }^{1}$ By business line, more than half the loss events are recorded under "other" in terms of frequency and severity. Again this is because the explicitly defined categories are applicable to banks only whereas the loss events considered here cover ten different corporate entity types. In terms of the explicitly defined business lines, trading and sales recorded the largest number of events but commercial banking endured the most severe losses. As for corporate entity types, 33 per cent of the loss events were endured by commercial banks, but in terms of severity non-financial firms endured more than half the total loss amount. ${ }^{2}$ One explanation for this observation is that commercial banks endure a large number of small losses resulting, for example, from credit card fraud.

Table 2 presents the results of the chi-square test of independence between event types, one the one hand, and business lines and corporate entity type on the other. In all cases the test statistic is significant, implying that the hypotheses 1-4 are rejected, which means that events of certain kinds tend to occur more frequently and with greater severity in certain business lines and corporate entity types. This, however, does not mean that the pattern is similar across countries and country groups.

\footnotetext{
${ }^{1}$ For example, companies that are forced to recall a faulty product typically incur huge losses.

2 This makes one wonder why the Basel rules on capital requirements are applied to banks only-not that these requirements serve any meaningful purpose.
} 
Consider, for example, the differences between the incidence of external fraud and internal fraud in China and the U.S. In China, Internal fraud is most frequent and most severe in commercial banking as a business line and commercial banks as a corporate entity type. In the U.S., internal fraud is most frequent and most severe in other business lines and in non-financial firms, but in China it is most frequent and most severe in commercial banking as a business line commercial banks as a corporate entity type. As for external fraud, it is most frequent in other business lines in China and in commercial banking in the U.S., whereas in terms of corporate entity type it is most frequent in commercial banks in both China the U.S. In terms of severity it is highset in non-financial firms in China and in commercial banking in the U.S.

In fact, the distribution of loss events varies considerably as shown in Table 3 and Table 4. In Table 3, we can see that internal fraud is the most frequent and severe loss event in five countries or country groups. In all other country groups the most frequent loss event is CPBP. In terms of severity, however, CPBP is the most severe event only in Japan and the U.S. In terms of the least frequent and least severe events, these are predominantly EDPM, BDSF and EPWS. Internal fraud is the most frequent loss event in Africa, China, Japan, the Middle East and Latin America. Table 4 reports the incidence of loss events across countries and country groups. Internal fraud is most frequent and most severe in China and less frequent/less severe in the U.K. External fraud, on the other hand, is most frequent in Latin America and least frequent in the U.S., but in terms of severity it is highest in Japan and lowest in East Asia.

How can we explain these cross-country differences? While it is rather difficult to explain precisely the differences arising in a certain situation a general explanation can 
be suggested. The description of operational risk gives an idea about what may determine the frequency and severity of operational losses. People risk is bound to depend on corporate governance, corruption, ethical standards, internal controls within firms, transparency and disclosure requirements, and management style. Process risk depends, inter alia, on regulation, transparency and disclosure requirements, and legal issues such as copyrights and patents. System risk depends, inter alia, on the state of technology. And external risk is determined by the severity of economic fluctuations, regulation, disclosure requirements, compliance requirements, and environmental standards. Since these factors are bound to be different across countries, the distribution and incidence of operational losses are bound to differ as well.

\section{Conclusion}

Our examination of 4388 loss events covering eleven countries or country groups reveal marked differences in the distribution and incidence of operational losses across countries in terms of both frequency and severity. There are differences with respect to the type of loss event prevailing in each country or country group. There are also differences with respect to the dominance of events of certain type in a particular business line and corporate entity type. These differences are attributed to crosscountry differences in the factors determining the frequency and severity of people risk, process risk, system risk and external risk. 


\section{References}

Bar, M., Cicotello, C.S. and Ruenzi, S. (2008) Does Team Management Reduce Operational Risk? Evidence from the Financial Services Industry, Working Paper, November. www.finance-innovation.org/risk09/work/9872842.pdf.

BCBS (2004) Basel II: International Convergence of Capital Measurement and Capital Standards: A Revised Framework, Basel: Bank for International Settlements, June.

Brown, S., Goetzmann, W. and Schwarz, C. (2007) Mandatory Disclosure and Operational Risk: Evidence from Hedge Fund Registration, Workin Paper. http://www.ecb.int/events/pdf/conferences/ecbcfs_conf9/Disclosure.pdf.

Chernobai, A., Jorion, P. and Yu, F. (2007) The Determinants of Operational Losses, Working Paper (Syracuse University, Syracuse, New York).

De Fontnouvelle, P., Dejesus-Rueff, V. Jordan, J. and Rosengren, E. (2005) Capital and Risk: New Evidence on Implications of Large Operational Losses, Journal of Money, Credit and Banking, 38, 1819-1846.

Herring, R.J. (2002) The Basel 2 Approach to Bank Operational Risk: Regulation on the Wrong Track, Paper Presented at the $38^{\text {th }}$ Annual Conference on Bank Structure and Competition, Federal Reserve Bank Of Chicago, 9 May.

Jobst, A.A. (2007) The Treatment of Operational Risk under the New Basel Framework: Critical Issues, Journal of Banking Regulation 8, 316-352.

Moosa, I.A. (2011) Operational Risk as a Function of the State of the Economy, Economic Modelling, 28, 2137-2142.

Pezier, J. (2003) A Constructive Review of The Basel Proposals on Operational Risk, In C. Alexander (ed), Operational Risk: Regulation, Analysis and Management, London: Prentice Hall-Financial Times. 
Table 1: Classification of Event Types, Business Lines and Corporate Entity Types

\begin{tabular}{|c|c|c|}
\hline Item & Symbol & Description/Example \\
\hline \multicolumn{3}{|l|}{ Event Type } \\
\hline Business Disruption and Systems & BDSF & Disruption or failure in systems \\
\hline \multicolumn{3}{|l|}{ Failure } \\
\hline Clients, Products and Business & СРВР & Failure to meet obligations to clients \\
\hline \multicolumn{3}{|l|}{ Practices } \\
\hline Execution, Delivery and Process & EDPM & Failed transaction processes \\
\hline \multicolumn{3}{|l|}{ Management } \\
\hline External Fraud & $\mathrm{EF}$ & Computer hacking, forgery, theft \\
\hline Employment Practices and Workplace & EPWS & Violation of employment and safety \\
\hline Safety & & laws \\
\hline Internal Fraud & IF & Bribes, forgery, insider trading \\
\hline \multicolumn{3}{|l|}{ Other } \\
\hline \multicolumn{3}{|l|}{ Business Line } \\
\hline$\overline{\text { Asset Management }}$ & $\mathrm{AM}$ & Retail, institutional \\
\hline Commercial Banking & CB & $\begin{array}{l}\text { Project finance, trade finance, bills of } \\
\text { exchange }\end{array}$ \\
\hline Corporate Finance & $\mathrm{CF}$ & Mergers and acquisitions, IPOs \\
\hline Payment and Settlement & PS & Funds transfer, clearing and settlement \\
\hline Retail Banking & $\mathrm{RB}$ & Private lending and deposits \\
\hline Trading and Sales & TS & Foreign exchange, repos \\
\hline \multicolumn{3}{|l|}{ Other } \\
\hline \multicolumn{3}{|l|}{ Corporate Entity Type } \\
\hline Central Bank & CB & \\
\hline Commercial Bank & COMB & \\
\hline Investment Bank & IB & \\
\hline Finance Company & FC & \\
\hline Insurance Company & IC & \\
\hline Brokerage Firm & $\mathrm{BF}$ & \\
\hline Building Society/Credit Union & BSCU & \\
\hline Government Entity & GE & \\
\hline Non-Financial Firm & NFF & \\
\hline Professional Services & PS & \\
\hline
\end{tabular}


Table 2: The Chi-Square Statistics for the Four Hypotheses (x 10²)

\begin{tabular}{|l|c|c|c|c|}
\hline & H1 & H2 & H3 & H4 \\
\hline Africa & 0.31 & 76.39 & 0.27 & 25.60 \\
\hline Canada & 0.45 & 215.51 & 0.32 & 171.11 \\
\hline China & 0.55 & 122.29 & 0.42 & 161.11 \\
\hline East Asia & 0.55 & 548.73 & 0.74 & 534.04 \\
\hline Europe & 0.74 & 245.53 & 0.97 & 256.90 \\
\hline Japan & 0.68 & 37.17 & 0.41 & 252.08 \\
\hline Middle East & 0.45 & 57.24 & 0.52 & 96.34 \\
\hline Oceania & 0.53 & 105.06 & 0.52 & 115.72 \\
\hline Latin America & 0.35 & 83.01 & 0.38 & 7923.29 \\
\hline U.K. & 1.38 & 917.23 & 1.45 & 1028.16 \\
\hline U.S. & 6.01 & 2115.01 & 3.30 & 3622.08 \\
\hline Total & 7.94 & 248.18 & 5.18 & 4761.55 \\
\hline
\end{tabular}


Table 3: The Highs and Lows of Loss Events Across Countries/Regions

\begin{tabular}{|l|c|c|c|c|}
\hline \multicolumn{1}{|c|}{ Country/Region } & \multicolumn{2}{c|}{ Frequency } & \multicolumn{2}{c|}{ Severity } \\
\hline & High & Low & High & Low \\
\hline Africa & IF & BDSF & IF & EDPM \\
\hline Canada & CPBP & BDSF & OTHER & EPWS \\
\hline China & IF & EPWS & IF & EPWS \\
\hline East Asia & CPBP & EPWS & OTHER & EPWS \\
\hline Europe & CPBP & BDSF & IF & EPWS \\
\hline Japan & IF & EPWS & CPBP & BDSF \\
\hline Middle East & IF & EPWS & IF & OTHER \\
\hline Oceania & CPBP & OTHER & EDPM & EPWS \\
\hline Latin America & IF & BDSF & IF & BDSF \\
\hline U.K. & CPBP & BDSF & OTHER & BDSF \\
\hline U.S. & CPBP & BDSF & CPBP & BDSF \\
\hline
\end{tabular}


Table 4: The Incidence of Operational Loss Events across Countries/Regions

\begin{tabular}{|l|c|c|c|c|}
\hline \multicolumn{1}{|c|}{ Loss Event } & \multicolumn{2}{c|}{ Frequency } & \multicolumn{2}{c|}{ Severity } \\
\hline & High & Low & High & Low \\
\hline BDSF & Japan & Latin America & China & Japan \\
\hline CPBP & Europe & China & Africa & Oceania \\
\hline EDPM & Oceania & China & U.K. & China \\
\hline EF & Latin America & U.S. & Japan & East Asia \\
\hline EPWS & U.S. & China & Africa & China \\
\hline IF & China & U.K. & China & U.K. \\
\hline Other & Europe & Oceania & East Asia & Middle East \\
\hline
\end{tabular}


Figure 1: The Distribution of Operational Losses

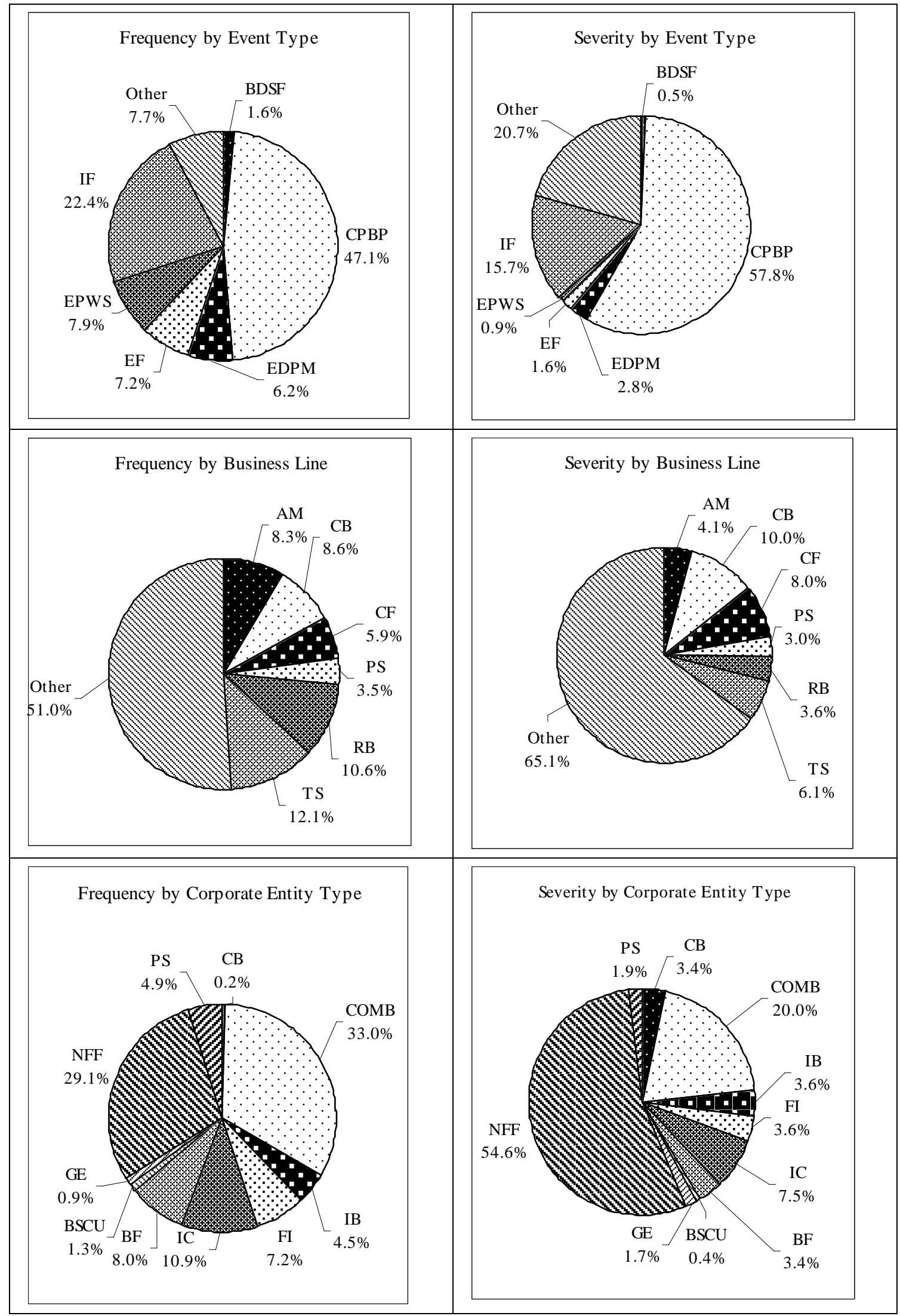

